\title{
Information asymmetry and accounting conservatism: Does analyst coverage moderate the results?
}

\author{
Atik Isniawati \\ Universitas Sebelas Maret \\ Faculty of Economics, Universitas Darma Persada \\ Indonesia \\ atik.unsada@yahoo.co.id \\ Rahmawati Rahmawati \\ Faculty of Economics and Business, Universitas Sebelas Maret \\ Indonesia \\ rahmaw2005@yahoo.com
}

\author{
Ardi Gunardi \\ Faculty of Economics and Business, Universitas Pasundan \\ Indonesia \\ ardigunardi@unpas.ac.id
}

Abstract. This study aims to examine the effect of information asymmetry on accounting conservatism moderated by analyst coverage. Net assets are measured to determine accounting conservatism. Information asymmetry is measured with the bid-ask spread, whereas analyst coverage is calculated using a proxy of analyst following. The sample in this research consists of manufacturing companies listed on the Indonesia Stock Exchange from 2010 to 2014. Data are gathered using purposive random sampling method, and the financial statement reports of 124 companies are selected. Regression test results are consistent with the hypothesis, that is, a positive correlation exists between information asymmetry and accounting conservatism. Additional evidence shows that the level of analyst coverage affects the relationship between information asymmetry and accounting conservatism. A high level of analyst coverage reduces the level of information asymmetry and decreases that of conservatism in financial statements.

Keywords: accounting conservatism; information asymmetry; analyst coverage; Indonesia.

JEL Classification: M41 


\section{INTRODUCTION}

The financial crisis that hit Indonesia in mid-1997 did not end the same year but widened into an economic crisis. Economic conditions began to improve only in the beginning of 1999. In the same year, significant investments started to flow into Indonesia. In 2001, 31 issuers were registered at the Indonesia Stock Exchange (BEI). In the subsequent years, the number decreased dramatically to only five issuers. Media in Indonesia reported that approximately 23 companies were doing IPOs in BEI in 2012. In the next year, BEI targeted 30 new issuers listed by its board. This target increased compared with the 25 companies of the previous year (Safitri, 2012). However, during 2007-2012, an underpricing phenomenon was observed in 104 of the 126 companies that did IPOs. Eighteen companies suffered from overpricing, and three companies had an initial return of zero.

Shi-yu and Chang (2008) state that the IPO underpricing phenomenon in various capital markets internationally is caused by information asymmetry. Information asymmetry can occur between issuers and underwriters, as well as between investors. Gao et al. (2008) claim that information asymmetry is caused by the gap between investors with information and those without. LaFond and Watts (2008) deduce that information asymmetry varies depending on a company's investment opportunity set. Growth option cannot be verified as investment grows; thus, information asymmetry between managers and outside investors escalates (Smith \& Watts, 1992). In these conditions, managers tend to hide future cash flows from a number of investments that cannot be verified. This course of action ensures that their performance looks good when reflected in financial statements.

The magnitude of information asymmetry can be reduced by the issuance of the prospectus by financial analysts. This prospectus normally contains both financial and non-financial information. It assists investors in making rational decisions about the risks of shares' real value offered by an issuer. Sun and Liu (2011) state that financial analysts can directly or indirectly affect management in choosing an accounting method. A direct effect can also occur due to the publication of research reports or through asking questions as the analysts interact with management. The indirect effect on the monitoring role of management takes place through mechanisms such as the board of directors and external auditors so that a company's financial reporting is monitored efficiently. High analyst coverage can limit the emergence of information asymmetry between management and outside investors in its role as an information intermediary.

LaFond and Watts (2008) argue that accounting conservatism may reduce managers' incentives and ability to manipulate, thus also reducing information asymmetry. Several previous studies argue that conservatism affects information asymmetry. However, LaFond and Watts (2008) estimate that information asymmetry may change when growing investments and growth options cannot be verified. Their study shows that great information asymmetry corresponds to a high level of accounting conservatism. Managers inevitably become increasingly conservative to decrease information asymmetry and thus maintain their company's credibility. Doing so makes investors think twice about reinvesting. Sun and Liu (2011) find that more analyst coverage causes higher conservatism and ultimately lower information asymmetry. Researching the effects of information asymmetry on accounting conservatism, moderated by analyst coverage, is interesting. Basu (1997) explains that the principle of conservatism is closely related to how report earnings reflect "bad news" faster than "good news." The study suggests that the "news" can be measured using the return of shares traded and the level of sensitivity of earnings to the negative return, two to six times.

This research is motivated by the underpricing phenomenon of PT Krakatau Steel IPO, which became the talk of various parties, both government and public. PT Krakatau Steel is the state-owned steel company (BUMN) and has good performance. At the time of its IPO, traded shares were expected to be able to provide large profits for the company's further progress. In addition, PT Krakatau Steel is guaranteed by three underwriters of considerable prestige, namely, PT Bahana Securities, PT Danareksa Securities, and PT 
Mandiri Securities. However, at the time of the IPO (November 10, 2010), PT Krakatau experienced underpricing, with the IPO price of Rp850 and closing price of Rp1,270. Some economic observers stated that this underpricing happened due to a human error by the BUMN minister while setting the price for the shares, but others believed it was caused by information asymmetry (Safitri, 2012).

We select the sample period of 2010-2012 because investment growth has culminated since the 1999 crisis and has been marked by the number of companies conducting IPOs (2007-2012). However, during 2010-2012, the level of IPO underpricing was quite high, presumably due to information asymmetry in the issuer's financial statements. This presumption is supported by Shi-yu and Chang (2008), who state that the phenomenon of IPO underpricing occurs in various capital markets around the world because of information asymmetry. Therefore, we choose 2010-2014 as the sample period for our analysis. We add two years afterwards (2013 and 2014) to see whether the effect of information asymmetry was still present two years later.

To the best of our knowledge, this study is the first to test the influence of asymmetric information on accounting conservatism with analyst coverage as the moderating variable. Several previous similar studies examine only the relationship between information asymmetry and accounting conservatism or the relationship between analyst coverage and accounting conservatism. Many of these studies find that analyst coverage is one of the corporate governance mechanisms that may restrict managers' opportunistic behavior, thus reducing information asymmetry that ultimately reduces accounting conservatism. However, no previous studies examine directly the role of analyst coverage in strengthening the relationship between information asymmetry and accounting conservatism. On this background, this study attempts to test the effects of information asymmetry on accounting conservatism moderated by analyst coverage. This study also aims to determine the role of analyst coverage in the relationship between information asymmetry and accounting conservatism.

This research is expected to provide input for regulators and standard-setting official bodies on the important role of accounting conservatism for financial statement users. The results of this study are also expected to provide information on the role of an analyst as a party that encourages the provision of accurate financial statements to reduce information asymmetry and managers' opportunistic behavior. External monitoring of managers is one of the mechanisms used in corporate governance today.

\section{LITERATURE REVIEW}

Accounting conservatism is the verification difference between gain and loss recognition, resulting in the persistent understatement of the reported net asset value (Basu, 1997; Holthausen \& Watts, 2001; LaFond \& Watts, 2008). This definition is consistent with that of Bliss (1924) in Watts (2003) that accounting conservatism is traditionally described as the proverbial "do not anticipate a profit but anticipate all losses." That is, the recognition of gains before the legal claims against the income received is allowed if the revenues can already be verified. By contrast, loss recognition does not require high verification. However, it raises criticism of accounting conservatism from the capital market regulator, standard body, and academics, stating that the understatement of the asset value this period will bring an earnings overstatement in the coming period due to the expense understatement in future periods (Watts, 2003).

However, such a criticism only illustrates the use of accounting conservatism to see the impact on the income statement for a definite period. Accounting conservatism shows the impact on the cumulative financial reported in the statement of financial position and profit or cumulative profit since a company's operation. Thus, the understanding of accounting conservatism by these critics does not correspond to the actual definition. The influence of accounting conservatism on accounting practices is significant and has been for a long time (more than 500 years). The effect has increased during the last 30 years (Basu, 1997; 
Watts, 2003; Manganaris et al., 2011; Hamdan et al., 2012), proving that the reasons expressed by critics are weak and ignore the substantial benefits over accounting conservatism. Eliminating the principles of accounting conservatism from the standard is damaging for the presentation of financial information.

Researchers have found evidence of the benefits of accounting conservatism. Lobo and Zhou (2006) compare the levels of accounting aggressiveness in the period before and after SOX by comparing multiple conservatism measurements. The average company is more conservative in its financial reporting after SOX than before SOX, as indicated by lower discretionary accruals after SOX compared with that of before SOX. With a sample of 39 companies listed in the Amman Stock Exchange during the period 2001-2006, Hamdan et al. (2012) prove that although accounting conservatism is controversial and much criticized, the concept remains in use and plays an important role in accounting practices. Many factors affect the increase of conservatism in accounting (e.g., changes in the pattern of awarding compensation, litigation risks, and changes in accounting standards) by delaying gain recognition (Srivastava et al., 2015). Ball et al. (2008) state that accounting conservatism is applied more in countries that use accounting regulations based on the private sector rather than those based on the public sector.

Accounting conservatism also contributes to the emergence of agency problems. Basu (1997) states that conservatism will always be seen together with agency theory, which can solve the problems that arise between managers and shareholders. When the financial statements issued by the management are conservative (Watts, 2003), shareholders think twice about reducing the salaries of management but tend to compensate with attributes that are difficult to attain with the private interests of management. Ahmed and Duellman (2007) also find that accounting conservatism helps reduce agency costs.

Stiglitz (2002) explains that information asymmetry occurs when "different people know different things." Scott (2012) argues that if several parties involved in a business transaction do not have the same information or one party has more information than others, then information asymmetry exists. Information asymmetry usually occurs between the inside (including management) and outside investors.

Information asymmetry always appears in an agency relationship in which one party receives information that is different from what the other party acquires. Jensen and Meckling (1976) add that if the agent and principal seek to maximize their utility, then the agent will not always act in the best interest of the principal. The management, that is, the managers of the company, knows almost all the information, whether private or public, whereas outside investors acquire public information only (Rahmawati, 2006). The existence of private information raises information asymmetry between parties that hold the information and those with the potential to make a better decision if they receive the information (Connelly et al., 2011).

Managers have ample time to manipulate and overstate, and doing so will divert the efforts from increasing the value of the company, resulting in agency cost and reducing the value of the company in the next period (LaFond \& Watts, 2008). By contrast, managers can use this information to try to move the advantage of investors to their welfare (Watts, 2003). Thus, the principal can limit information asymmetry by setting the right incentives for agents and create a monitoring mechanism that is designed to constrain the activities of agents who deviate (Jensen \& Meckling, 1976). Agency theory explains that conflict between the agent and the principal will always appear in a contradicting relationship. As the parties who submit funds to be managed by the management, investors should ensure that the decisions made by the management are free from opportunistic behavior that only benefits the latter and is detrimental to shareholders. Therefore, outsiders must always supervise the decisions made by agents.

Corporate governance is a set of mechanisms to ensure that company assets are used efficiently so that suppliers are guaranteed their investments and stakeholders are protected against inappropriate asset distribution activities by management. The implementation of adequate corporate governance results in enhanced monitoring of management (García Lara et al., 2007; Widyaningsih et al., 2017; Honggowati et al., 
2017). Yu (2008) studies the direct effect of an analyst's role in corporate governance. The study tries to collect evidence about the role of the analyst, whether as an external monitor for managers or someone putting excessive pressure on them. Analysts who act as external monitors (Sun \& Liu, 2011) must carefully separate accurate information from inaccurate one because much of the information generated by accounting (e.g., profit and net assets) is timely and informative but not easily verified. Yu (2010) describes the role of analysts as information intermediaries. The accuracy of analyst forecasts is positively related to the quantity of corporate governance disclosure; otherwise, the dispersion of analyst forecast is negatively related to the quantity of corporate governance disclosure as measured by transparency and rank scores ( $\mathrm{Yu}$, 2008). Yu (2008) also explores the influence of managers' behavior on the occurrence level earning management in financial statements. Results show that firms with high analyst coverage have lower discretionary accrual than those with low coverage.

LaFond and Watts (2008) find that great information asymmetry between insider and outsider investors corresponds to a small reported profit, and vice versa (great reported losses) in financial statements. The results of this study show that information asymmetry affects the level of accounting conservatism. This finding is in contrast with that of previous researchers who argue that companies with a greater degree of conservatism have lower information asymmetry. They suppose that information asymmetry varies depending on a company's investment opportunity set. This supposition is supported by Smith and Watts (1992) and Gaver and Gaver (1993), who state that growth options cannot be verified. Thus, if the investment is growing, then the information asymmetry between managers and investors outsider is even greater, and IOS is assumed as an exogenous factor. Smith and Watts (1992) and Gaver and Gaver (1993) claim that conservatism varies positively with information asymmetry.

Sun and Liu (2011) test the variables that affect conservatism. They find that analyst coverage affects the level of accounting conservatism. Their research provides strong evidence of a positive relationship between analyst coverage and accounting conservatism. That is, the company is more conservative when they are followed by many analysts than when they are followed by fewer analysts. Information asymmetry can be minimized by the assessment of financial analysts. High analyst coverage can limit the emergence of information asymmetry between management and outside investors in its role as information intermediary. LaFond and Watts (2008) argue that accounting conservatism may reduce the incentives and manipulative behavior of managers, ultimately reducing information asymmetry and the level of accounting conservatism. $\mathrm{Yu}$ (2008) provides evidence that firms with high analyst coverage have smaller earning management than those with low coverage. A review of an analyst acts as a monitoring tool of management performance and hampers managers' opportunistic behavior. On the basis of this literature, the authors of the present study propose the following hypothesis:

Hypothesis: Analyst coverage moderates the relationship between information asymmetry and accounting conservatism in financial statements.

\section{METHODOLOGY}

The population consists of manufacturing companies listed in BEI during 2010-2014. Data are obtained using purposive random sampling method with the following criteria: available financial reports and stock prices on www.idx.co.id and still in operation during the observation period. A total of 145 companies were listed on BEI during 2010-2014. Four companies were delisted between 2010 and 2014. Sixteen new companies did IPOs between 2011 and 2014. In addition, one company did not complete its stock price information. Thus, 124 companies meet the criteria, with a total of 620 observations.

This study uses accounting conservatism as the dependent variable, information asymmetry as an independent variable, and analyst coverage as the variable that moderates the relationship between 
information asymmetry and accounting conservatism. This study also adopts two control variables, namely, firm size and leverage.

Accounting conservatism is determined by measuring the net assets, that is, market-to-book ratio. This measure is based on the definition of accounting conservative as oriented balance sheet, which is suggested by Feltham and Ohlson (1995) in Givoly and Hayn (2000). The use of market-to-book ratio or price-tobook value ratio as a proxy for accounting conservatism is based on the fact that conservatism is ultimately reflected in the understatement of assets and overstatement of liabilities (Lo, 2005). According to Givoly and Hayn (2002), market-to-book ratio is a manifestation of market valuation response on the net assets of companies relative to the book value, indicating understated assets or overstated liabilities. If the value of the market-to-book ratio is greater than 1, then it indicates conservativism. The increase in the ratio over time shows an increase in the application of accounting conservatism, assuming other things remain. Market-to-book ratio is calculated by the market value of the common stock, namely, the number of outstanding shares multiplied by the share price at the end of the year, divided by its book value (Ong \& $\mathrm{Ng}, 2018$ ).

This study uses bid-ask spread to measure the magnitude of information asymmetry between agents and principals. This measure is used with the premise that the information asymmetry occurring between securities dealers affects the price. A large amount of private information corresponds to a great bid-ask spread and low returns to investors without private information; therefore, the equilibrium of stock return requirements is higher (LaFond \& Watts, 2008). Jones (2002) states that the bid-ask spread is the difference between the highest purchase price (ask) that leading investors are prepared to pay for a certain stock and the lowest selling price (bid) at which they are willing to sell their shares. The formula for calculating the bid-ask spread is expressed as follows:

$$
A I\left(\operatorname{SPRE} A D_{i, t}\right):\left(\left(A S K_{i, t}-B I D_{i, t}\right) \times 100 \% /\left\{\left(A S K_{i, t}+B I D_{i, t}\right) / 2\right\} \times 100 \%\right): \mathrm{N},
$$

where

$A I\left(S P R E A D_{i, t}\right):\left(A S K_{i, t}-B I D_{i, t}\right) /\left\{\left(A S K_{i, t}+B I D_{i, t}\right) / 2\right\} \times 100 \%$

$A S K_{i, i}$ the highest ask price (bid) of bank shares that occurred on days $i$ and $t$

$B I D_{i, t}$ the lowest bid price (ask) of bank shares that occurred on days $i$ and $t$

This study uses a proxy of analyst following as a measure to analyst coverage. $\mathrm{Yu}(2010)$ finds a positive relationship among analyst following, transparency, and disclosure of score ranking. This relationship indicates the quality improvement of the information issued by financial analysts. Given increased disclosure of information on corporate governance, financial analysts will be more attracted to follow the companies. Therefore, the quantity of the earning forecast available in the market will increase.

This study uses the size of the coverage analyst based on Yu's (2010) research with the adjustment of the general conditions prevailing in the Indonesian capital market. Proxies for analyst following in this study using a dummy variable to indicate the manufacturing companies are included in the LQ 45 index (score 1), given that companies that have the most active stock transactions are followed by many financial analysts, while others are given a score of 0 , assuming companies with stocks that are less or not active.

The author uses the control variables of firm size (SIZE) and leverage (LEV). Company size is related to the level of accounting conservatism because large companies are usually monitored by government and society. The government will tend to raise taxes and require large companies that report relatively permanently high earnings to provide society with excellent services. Therefore, large companies tend to report relatively permanently lower profits by applying conservative accounting (Lo, 2005).

The second control variable is leverage. Leverage is related to accounting conservatism because if companies have high levels of debt, then the creditor will have the right to increase its monitoring of the 
operation and management of the company. Increased monitoring will be able to reduce the information asymmetry between creditors and management. Creditors have an interest in reporting lower net assets and profits to maintain the rate of return on companies' debt, thereby encouraging management to use conservative accounting.

To test the research hypothesis, this study uses the following equation:

$$
C O N S=a+\beta 1 A I+\beta 2 A C+\beta 3 A I^{*} A C+\beta 4 S I Z E+\beta 5 L E V+\varepsilon
$$

Where:

CONS : accounting conservatism, measured by market-to-book ratio (Hamdan et al., 2012).

AI : information asymmetry, measured by the difference between the ask and bid (Jones, 2002).

AC : analyst coverage, measured by a dummy variable. Figure 1 shows the companies included in the group LQ 45 and 0 otherwise.

SIZE : company size measured by the logarithm of total assets.

LEV : leverage measured by debt-to-assets ratio.

In this equation, all variables have the same definition as described previously. This hypothesis predicts the influence of information asymmetry on accounting conservatism and analyst coverage as moderating variables. The objective is to determine the effect of moderating variables, that is, whether they strengthen or weaken the effect of information asymmetry on accounting conservatism. On the basis of the tests to be performed, if $\beta 1$ showed a positive value, which indicates greater information asymmetry between managers and outside investors, then accounting conservatism is practiced considerably. The influence of moderating variables on the relationship of information asymmetry on conservatism can be seen by comparing adj. $\mathrm{R}^{2}$ value before and after it is moderated. If the value of $\mathrm{R}^{2}$ increases and the interaction coefficient of the information asymmetry and the analyst coverage is significant, then the variable of analyst coverage moderates the relationship of information asymmetry and accounting conservatism.

A sensitivity analysis was performed to compare and examine conservatism proxies by using suitable assumed models to explain the conservatism applied in the financial statements. This study uses market-tobook ratio (net assets measures) and Basu's (1997) model (earnings/stock return relation measures) as proxies of accounting conservatism. Both are a measure of the asymmetry verifiability on gains and losses that resulted in an understated report of the net asset. Great asymmetry verifiability corresponds to great understatement of net asset reporting. The two proposed models are as follows:

CONS $=a+\beta 1 A I+\beta 2 A C+\beta 3 A I^{*} A C+\beta 4 S I Z E+\beta 5 L E V+\varepsilon \ldots$ (1)

$E P S=a+\beta 1 P o N+\beta 2 R E T+\beta 3 R E T * P o N+\beta 4 A I+\beta 5 A I^{*} P o N+\beta 6 A I^{*} R E T+\beta 7 A I^{*} R E T * P o N+$ $\beta 8 A C+\beta 9 A C^{*} \mathrm{PoN}+\beta 10 A C^{*} \mathrm{RET}+\beta 11 A C^{*} \mathrm{RET}{ }^{*} \mathrm{PoN}+\beta 12 A C^{*} A I^{*} \mathrm{RET}{ }^{*} \mathrm{PoN}+\beta 13 S I Z E+\beta 14 L E V$ $+\varepsilon \ldots(2)$

Where:

CONS : accounting conservatism, as measured by the market-to-book ratio (Hamdan et al., 2012).

AI : information asymmetry, as measured by the difference between the ask and bid (Jones, 2002).

AC : analyst coverage as measured by a dummy variable. Figure 1 shows the companies included in the group LQ 45 and 0 otherwise.

SIZE : company size measured by the logarithm of total assets.

LEV : leverage as measured by debt-to-assets ratio.

EPS $_{\mathrm{i}, \mathrm{t}} \quad$ : earnings per share for the company $\mathrm{i}$ in year $\mathrm{t}$. 
$\mathrm{P}_{\mathrm{it}-1} \quad: \quad$ share price of firm $\mathrm{i}$ at the beginning of $\mathrm{t}$.

$\mathrm{PoN}_{\mathrm{i}, \mathrm{t}} \quad$ : dummy variable whose value is 1 if the return of firm $\mathrm{i}$ in year $\mathrm{t}$ is negative and 0 otherwise.

RET $_{\mathrm{i}, \mathrm{t}} \quad$ : return of firm $\mathrm{i}$ from 9 months before the fiscal year ends $t$ to 3 months after the fiscal year ending $t$.

$\mathrm{RETPON}_{\mathrm{i}, \mathrm{t}}$ : annual logarithm difference in the stock price at the end of the year $\mathrm{i} t$ multiplied by the respective dummy DT.

Model 1 measure conservatism using the market-to-book ratio, while model 2 measures conservatism by using Basu's model. This study chooses Basu's model to measure the sensitivity because its size is consistent with the definition of accounting conservatism. In addition, this measure meets the objective of this paper, namely, to describe agency conflict between the agent and the principal where the stock price and stock return is information that is more reliable because it is determined by the market unlike other measures, such as discretionary accruals that all data measurement derived from the internal company. Another advantage is that this model is only used to measure conservatism alone, while discretionary accrual is not only used to measure conservatism but is also used by many other researchers to measure earnings management.

Timely recognition of the losses (bad news) and the gains (good news) reflected in earnings is an explanation that supports the concept of accounting conservatism according to Basu's model, in which he claimed that the negative return is more quickly recognized in profits than a positive return. Basu's model looks at the conservatism level from the interaction between return with dummy return, where 1 indicates positive returns, and 0 indicates a negative return. This concept means that a high $\beta 3$ coefficient corresponds to a great level of accounting conservatism practice.

Basu's model is tested to compare the magnitude of the coefficient $\beta 12 \mathrm{AC}^{*} \mathrm{AI} * \mathrm{RET} * \mathrm{PoN}$ (model after moderation) with a coefficient of $\beta 7 A I *$ RET*PoN (model before moderation). If the coefficient of $\beta 12 \mathrm{AC}^{*} \mathrm{AI} * \mathrm{RET} * \mathrm{PoN}$ is positive and significant, and the value is greater than the coefficient $\beta 7 \mathrm{AI} * \mathrm{RET} * \mathrm{PoN}$, then the effects of information asymmetry on conservatism are strong. This idea means that a great information asymmetry between managers and outside investors corresponds to a great level of accounting conservatism practice. This finding is also supported by the results of Adj. $\mathrm{R}^{2}$, which shows a higher value of moderation. Sensitivity analysis is performed by comparing the coefficient $\beta 3$ in the equation with the conservatism proxy of the market-to-book ratio with $\beta 12$ in the equation with Basu's model, and the level of significance of each coefficient is observed.

\section{EMPIRICAL RESULTS AND DISCUSSION}

Table 1 shows that the average of conservatism (CONS) is positive and less than 1 during the observation period (2010-2014) with a value of 0.8687 . This finding indicates that manufacturing companies in Indonesia have relatively low accounting conservatism levels (Hamdan et al., 2012). In accordance with the assumptions-based Financial Accounting Standards regarding the selection method of inventory, depreciation of fixed assets, intangible assets, and recognition of research and development costs, companies that choose the method that produces high costs have higher conservatism than the companies that choose the method that results in low costs. Consistent with these assumptions, the average of the sample chose a method that produces a smaller cost so that the net book value of equity shares is larger than the market value of the common equity. Thus, the ratio of the market value to the book value of common equity (market value of common equity/book value of common equity) becomes smaller or less than 1 .

The average information asymmetry in Table 1 is $2.16 \%$. This result indicates that the information asymmetry between inside and outside investors in manufacturing companies in Indonesia is relatively small for the period of 2010-2014. The information asymmetry in this study is obtained using a proxy bid-ask 
spread, which is the difference between the highest purchase price (bid-price), thereby causing investors to become willing to buy a particular stock with the lowest selling price (the ask-price). Thus, investors are willing to sell their shares. The minimum and the maximum value of this variable is zero (0) and $6.03 \%$, respectively, thereby showing the difference is relatively small with a standard deviation that is also relatively small (0.0145). The minimum value of bid-ask spread 0 indicates that some samples have a stagnant stock price (bid-ask price equal to the price). This idea means that several manufacturing companies in Indonesia are less or not active in trading their shares. Furthermore, the difference of minimum and maximum values of these variables is relatively little, thereby showing that the variation of data is not too large.

Table 1

Descriptive analysis

\begin{tabular}{|c|c|c|c|c|c|c|}
\hline Variable & Mean & Std & Q1 & Q3 & Minimum & Maximum \\
\hline CONS & 0.8687 & 0.8069 & 0.4575 & 1.040 & -0.1800 & 5.7000 \\
\hline AI & 0.0216 & 0.0145 & 0.0099 & 0.0313 & 0.0000 & 0.0603 \\
\hline AC & 0.0537 & 0.2257 & 0.0000 & 0.0000 & 0.0000 & 1.0000 \\
\hline AIAC & 0.0012 & 0.0056 & 0.0000 & 0.0000 & 0.0000 & 0.0399 \\
\hline LogSIZE & 0.7807 & 0.0460 & 0.7502 & 0.8058 & 0.6700 & 0.9229 \\
\hline LEV & 0.6899 & 27.414 & 0.3100 & 0.6600 & 0.0000 & 54.000 \\
\hline
\end{tabular}

The analyst coverage (AC) in Table 1 has a value of 21, which means that of the total sample, only 21 observations had a score of 1 or was in the group of the LQ45 index during the period of 2010-2014. Results showed that manufacturing companies in Indonesia are less active in stock transactions. The average logSIZE of 0.7807 indicates that the sample companies have average log total assets of 0.7807 . Lastly, the average leverage of 0.6899 indicates $68.99 \%$ of the average capital structure of manufacturing companies in Indonesia are sourced in debt.

This research hypothesis predicts that great information asymmetry corresponds to great asymmetry recognition of gains and losses in the current-period financial statements. Table 2 estimates the equation of the relationship information asymmetry and asymmetry of gain and loss recognition. Results showed a positive $(\beta 1)$ but not significant $(p=0.774)$ relationship between accounting conservatism and information asymmetry. This finding indicates that when the level of information asymmetry between the insider and uninformed investors increases, the earnings in the current period financial statements will also reflect a high level of conservatism.

Furthermore, Table 2 shows that analyst coverage is the moderating influence of information asymmetry on accounting conservatism (supported). The result is supported by the increased adj. $\mathrm{R}^{2}$ from 0.686 (before moderation) to 0.772 (after moderation). Increased adj. $\mathrm{R}^{2}$ proves that variable CONS in model 2 is more powerful, in which 0.772 explained by the independent variable, namely, information asymmetry (AI), which is controlled by the variable of firm size (SIZE) and leverage (LEV), while the rest $(0.228)$ is explained by other factors outside the model.

The role of analyst coverage as a moderating variable of the relationship between information asymmetry and accounting conservatism is also supported by the significance of the interaction between information asymmetry and analyst coverage. The criteria of decision-making are based on a significance level of $5 \%$. Results show that $Q$-value is less than $5 \%(0.000)$. Thus, the hypothesis is accepted, that is, the effect of information asymmetry variable on conservatism is stronger after being moderated by the analyst coverage variable. 
Regression analysis with proxy of conservatism: market-to-book ratio

\begin{tabular}{|l|c|c|}
\hline \multicolumn{2}{|l|}{ Equation } \\
\hline CONS $=a+\beta 1 A I+\beta 2 A C+\beta 3 A I^{*} A C+\beta 4 S I Z E+\beta 5 L E V+\varepsilon$ \\
\hline & Parameter & $\mathrm{p}$-Value \\
\hline Intercept & 0.730 & 0.057 \\
\hline AI & 0.443 & 0.748 \\
\hline AC & -0.105 & 0.702 \\
\hline AI*AC & 129.826 & 0.000 \\
\hline SIZE & -0.024 & 0.962 \\
\hline LEV & -0.016 & 0.030 \\
\hline & & \\
\hline Adj. $\mathrm{R}^{2}$ & 0.772 & \\
\hline
\end{tabular}

The results of this study are consistent with those of the previous studies conducted by LaFond and Watts (2008), which state that great information asymmetry between insider and outsider investors corresponds to high asymmetry of gain and loss recognition applied to financial statements.

This study also provides evidence that supports LaFond and Watts' (2008) idea that information asymmetry affects accounting conservatism rather than vice versa. Information asymmetry will increase in line with investment growth. Information asymmetry will vary in proportion to the company's investment opportunity set. Growth option cannot be verified. This concept means that cash flow from the investment will be difficult to verify the realization. Thus, uncertainty increases, which increases the information asymmetry as a result and causing a company to practice high accounting conservatism to suppress it. Thus, information asymmetry changes proportionally to the growth of investment, not vice versa.

Conservatism is a non-systematic mechanism that forces management to apply it to maintain the company's credibility. Hellman (2008) states that the practice of accounting conservatism is able to enhance the credibility of the company, and its predictive capabilities will limit the opportunistic behaviour of managers. Credibility is important to attract investors. An investment that continues to grow is good for the company's development, but it will almost certainly increase the information asymmetry. To defend it, the management will increase its practice of conservatism.

Basu (1997) states that conservatism will always be seen together with agency theory. Jensen and Meckling (1976) add that if the two groups (the agent and the principal) are people who seek to maximize their utility, then we have a strong reason to believe that the agent will not always act in the best interest of the principal. The management of a company knows almost all the information, whether it is private or public, whereas outside investors acquire public information only (Rahmawati, 2006). The existence of private information raises information asymmetry between the parties that hold the information, and the parties have the potential to make a better decision if they receive information (Connelly et al., 2011). Ahmed and Duellman (2007) proved that accounting conservatism will reduce agency costs. In contacting relation, either contracting debts and compensation, the application of accounting conservatism in the financial statements will reduce agency costs that arise because of the information asymmetry between parties who do the hiring and their inability to further verify private information (LaFond \& Watts, 2008). Thus, conservatism is a contracting mechanism that is efficient both in conditions of formal contracting or in the absence of formal contracting (Watts, 2003).

This study adds the variable of analyst coverage to determine the influence of this variable on the relationship between information asymmetry and accounting conservatism. The relationship between 
information asymmetry and accounting conservatism becomes strong and significant after being moderated by analyst coverage. The equation of the study model indicates that great information asymmetry between managers and outside investors corresponds to the practice of high accounting conservatism by the company after being moderated by analyst coverage (adj. $\mathrm{R}^{2}$ before moderation $<$ adj. $\mathrm{R}^{2}$ after moderation, p-value $<5 \%$ ). Sun and Liu (2011) found that analyst coverage has a positive and significant effect on the level of accounting conservatism. Thus, their study supports the results of the present study, that is, a company will be more conservative when it is followed by many analysts than when it is followed by fewer analysts. Thus, the review of an analyst is able to act as a monitor of management performance and hampers a company's opportunistic behaviour.

Table 3 shows the results of regression testing with two proxy conservatism, i.e., market-to-book ratio or proxy 1 (net assets measures) and Basu's model or proxy 2 (earnings/stock return relation measures). Regression testing for proxy 1 in Panel A shows that the results of coefficient $\beta 3$ (AC*AI) are positive and significant $(\mathrm{p}<0.05)$. For proxy 2 in Panel $B$, the interaction coefficient of AC*AI*RET*PoN $(\beta 12)$ is positive but not significant $(p>0.05)$. This analysis is followed by observing the change of the adj. R2 difference before and after being moderated. Adj. $\mathrm{R}^{2}$ for proxy 1 increases before and after being moderated by 0.608 (before moderation $=0.686$, after moderation $=0.772$ ). In proxy 2 , adj. $\mathrm{R}^{2}$ before moderation is 0.272 and 0.571 after moderation, indicating an increase of 0.299$)$.

The comparison of coefficient $\beta 3$ on proxy 1 and $\beta 12$ on proxy 2 shows positive signs that indicate a positive relationship between information asymmetry and accounting conservatism, that is, great information asymmetry corresponds to a great level of accounting conservatism. This idea is reinforced by the increase in adj. $\mathrm{R}^{2}$ before and after being moderated by the variable of analyst coverage for both proxies. However, differences are observed in the level of significance of interaction variables in proxy AC*AI by proxy 1 ( $\mathrm{p}$-value $<0.05$ ) and interaction variable of AC*AI*RET*PoN by proxy 2 ( $\mathrm{p}$-value $>0.05$ ). These results indicate that the proxy 1 relationship between variable information asymmetry and accounting conservatism is moderated by analyst coverage, whereas for proxy 2 , the variable of analyst coverage failed to moderate the two variables. Therefore, the test results of proxies 1 and 2 are not robust.

Table 3

Comparison of regression results with proxies 1 and 2

\begin{tabular}{|l|c|c|}
\hline \multicolumn{2}{|l|}{ Panel A } \\
\hline Equation \\
\hline CONS $=a+\beta 1 A I+\beta 2 A C+\beta 3 A I^{*} A C+\beta 4 S I Z E+\beta 5 L E V+\varepsilon$ \\
\hline & Parameter & - -Value \\
\hline Intercept & 0.730 & 0.057 \\
\hline AI & 0.443 & 0.748 \\
\hline AC & -0.105 & 0.702 \\
\hline AI*AC & 129.826 & 0.000 \\
\hline SIZE & -0.024 & 0.962 \\
\hline LEV & -0.016 & 0.030 \\
\hline & & \\
\hline Adj. $\mathrm{R}^{2}$ & 0.772 & \\
\hline
\end{tabular}


Comparison of regression results with proxies 1 and 2

\begin{tabular}{|c|c|c|}
\hline \multicolumn{3}{|l|}{ Panel B } \\
\hline \multicolumn{3}{|l|}{ Equation } \\
\hline \multicolumn{3}{|c|}{$\begin{array}{l}E P S=a+\beta 1 P o N+\beta 2 R E T+\beta 3 R E T * P o N+\beta 4 A I+\beta 5 A I^{*} P o N+\beta 6 A I^{*} R E T+\beta 7 A I^{*} R E T * P o N+\beta 8 A C+ \\
\beta 9 A C^{*} P o N+\beta 10 A C * R E T+\beta 11 A C^{*} R E T * P o N+\beta 12 A C^{*} A I^{*} R E T * P o N+\varepsilon\end{array}$} \\
\hline & Parameter & $\mathrm{p}$-Value \\
\hline Intercept & -2.525 & 0.000 \\
\hline PoN & -0.111 & 0.525 \\
\hline RET & 182.848 & 0.000 \\
\hline RET*PoN & -195.038 & 0.220 \\
\hline AI & -2.574 & 0.304 \\
\hline $\mathrm{AI} * \mathrm{PoN}$ & -0.654 & 0.924 \\
\hline AI*RET & 1202.410 & 0.130 \\
\hline AI*RET*PoN & 18708.018 & 0.030 \\
\hline $\mathrm{AC}$ & -0.188 & 0.088 \\
\hline $\mathrm{AC} * \mathrm{PoN}$ & 0.143 & 0.629 \\
\hline AC*RET & -214.495 & 0.000 \\
\hline AC*RET*PoN & 41.805 & 0.907 \\
\hline AC*AI*RET*PoN & 11981.298 & 0.581 \\
\hline Adj. $\mathrm{R}^{2}$ & 0.571 & \\
\hline
\end{tabular}

Beaver and Ryan (2000) state that the size of the market-to-book ratio is appropriately used as a proxy for conservatism for companies that apply varying levels of conservatism. In descriptive statistics (Table 1), the minimum and maximum values of conservatism variables have a sufficiently large distance, and the number of standard deviations is large. On the basis of this result, we can conclude that the level of accounting conservatism among manufacturing companies in Indonesia varies. Thus, the test results are consistent with the hypothesis of Beaver and Ryan (2000). Another research that supports the present study is that of Lo (2005), which states that the company size is related to the level of accounting conservatism because large companies are usually monitored by the government and society. The government will tend to raise taxes and demand more excellent services from large companies that report relatively permanently high earnings. Therefore, large companies tend to report relatively permanently low profits to achieve more conservative accounting.

\section{CONCLUSION}

This study is the first to examine the relationship between information asymmetry and accounting conservatism moderated by the variable of analyst coverage. Our results are positive and significant, which means that the relationship of information asymmetry on accounting conservatism is positive and moderated by the variable of analyst coverage. These results indicate that great asymmetry between information received by insiders and that received by uninformed investors corresponds to great conservatism, which is reflected in reported earnings. The results are consistent with the research of LaFond and Watts (2008).

This study also provides evidence supporting LaFond and Watts' (2008) idea that information asymmetry affects accounting conservatism rather than vice versa. Information asymmetry will increase in line with investment growth. Information asymmetry will vary in proportion to the company's investment 
opportunity set. Growth option cannot be verified. Thus, cash flow from investments will be difficult to verify the realization that uncertainty increases, thereby increasing information asymmetry. For this reason, the company will practice high accounting conservatism to suppress it. Thus, information asymmetry changes proportionally to the growth of investment and not with accounting conservatism.

Conservatism is a non-systematic mechanism that forces management to apply it to maintain the company's credibility. Hellman (2008) states that the practice of accounting conservatism can enhance the credibility of a company, and its predictive capabilities will limit the opportunistic behaviour of managers. Credibility is important to attract investors. Continuously growing investments are good for a company's development, but they will almost certainly increase information asymmetry. To maintain a company's credibility, the management will increase its practice of conservatism.

The sensitivity analysis with two proxies of accounting conservatism, namely, market-to-book ratio (proxy 1) and Basu's model (proxy 2) obtained results that are not robust. Hypothesis testing with proxy 1 indicates that the relationship of information asymmetry and accounting conservatism is moderated by analyst coverage. However, with proxy 2 , the variable of analyst coverage failed to moderate information asymmetry and accounting conservatism. Beaver and Ryan (2000) explain why the sensitivity test results are not robust, stating that the size of the market-to-book ratio is appropriately used as a proxy for conservatism for companies that apply varying levels of conservatism. This explanation is in accordance with the sample conditions of this research.

This research has theoretical and practical implications. Its theoretical implications are as follows: 1) This research adds to the literature on the measurement of accounting conservatism with different proxies, with this study obtaining different results, and 2) it provides empirical evidence that a large amount of private information will cause an information gap between inside and outside investors, which in turn will encourage the practice of accounting conservatism. Its practical implications are as follows: 1) This research will assist investors in making an investment, especially in manufacturing companies, 2) provide evidence of the role of financial reporting analysts as another mechanism of corporate governance, whose existence investors need to consider when making investment decisions, and 3) provide evidence to regulators as to why they should be careful in making decisions to eliminate accounting conservatism given the importance of this principle as a non-systematic mechanism that can inhibit the opportunistic behavior of management.

The limitations of this study lie in the number of data samples that have unique characteristics, thereby making them outliers. We suspect that outlier data are caused by the striking difference in company size. In addition, this research was conducted only on manufacturing companies in Indonesia. Thus, companies with an extreme size in the sample cannot be tested. As a result, our results cannot be generalized. In future studies, market-to-book ratio and leverage should be added as control variables to control the size of the company. In addition, the research sample should be extended to other industry sectors to ensure that the results can be generalized.

\section{REFERENCES}

Ahmed, A. S., \& Duellman, S. (2007). Accounting Conservatism and Board of Director Characteristics: An Empirical Analysis. Journal of Accounting and Economics, 43(2-3), 411-437. http://doi.org/10.1016/j.jacceco.2007.01.005

Ball, R., Robin, A., \& Sadka, G. (2008). Is Financial Reporting Shaped by Equity Markets or By Debt Markets? An International Study of Timeliness and Conservatism. Review of Accounting Studies, 13(2-3), 168-205. http://doi.org/10.1007/s11142-007-9064-x

Basu, S. (1997). The Conservatism Principle and the Asymmetric Timeliness of Earnings. Journal of Accounting and Economics, 24(1), 3-37. http://doi.org/10.1016/S0165-4101(97)00014-1

Beaver, W. H., \& Ryan, S. G. (2000). Biases and Lags in Book Value and Their Effects on the Ability of the Book-toMarket Ratio to Predict Book Return on Equity. Journal of Accounting Research, 38(1), 127-148. 
Connelly, B. L., Certo, S. T., Ireland, R. D., \& Reutzel, C. R. (2011). Signaling Theory: A Review and Assessment. Journal of Management, 37(1), 39-67. http://doi.org/10.1177/0149206310388419

Gao, H., Darroch, J., Mather, D., \& MacGregor, A. (2008). Signaling Corporate Strategy in IPO Communication: A Study of Biotechnology IPOs on the NASDAQ. Journal of Business Communication, 45(1), 3-30. http://doi.org/10.1177/0021943607309349

García Lara, J. M., Osma, B. G., \& Penalva, F. (2007). Board of Directors' Characteristics and Conditional Accounting Conservatism: Spanish Evidence. European Accounting Review, 16(4), 727-755. http://doi.org/10.1080/09638180701706922

Gaver, J. J., \& Gaver, K. M. (1993). Additional Evidence on The Association Between the Investment Opportunity Set and Corporate Financing, Dividend, and Compensation Policies. Journal of Accounting and Economics, 16(1-3), 125-160. http://doi.org/10.1016/0165-4101(93)90007-3

Givoly, D., \& Hayn, C. (2000). The Changing Time-Series Properties of Earnings, Cash Flows and Accruals: Has Financial Reporting Become More Conservative? Journal of Accounting and Economics, 29(3), 287-320. http://doi.org/10.1016/S0165-4101(00)00024-0

Givoly, D., \& Hayn, C. (2002). Rising Conservatism: Implications for Financial Analysis. Financial Analysts Journal, 58(1), 56-74. http://doi.org/10.2469/faj.v58.n1.2510

Hamdan, A. M. M., Kukreja, G., Awwad, B. S. A., \& Dergham, M. M. (2012). The Auditing Quality and Accounting Conservatism. International Management Review, 8(2), 33-50.

Hellman, N. (2008). Accounting Conservatism under IFRS. Accounting in Europe, 5(2), 71-100. http://doi.org/10.1080/17449480802510492

Holthausen, R. W., \& Watts, R. L. (2001). The Relevance of The Value-Relevance Literature for Financial Accounting Standard Setting. Journal of Accounting and Economics, 31(1-3), 3-75. http://doi.org/10.1016/S01654101(01)00029-5

Honggowati, S., Rahmawati, R., Aryani, Y. A., \& Probohudono, A. N. (2017). Corporate Governance and Strategic Management Accounting Disclosure. Indonesian Journal of Sustainability Accounting and Management, 1(1), 23-30. http://doi.org/10.28992/ijsam.v1i1.24

Jensen, M. C., \& Meckling, W. H. (1976). Theory of the firm: Managerial behavior, agency costs and ownership structure. Journal of Financial Economics, 3(4), 305-360. http://doi.org/10.1016/0304-405X(76)90026-X

Jones, C. M. (2002). A Century of Stock Market Liquidity and Trading Costs. SSRN Electronic Journal.

LaFond, R., \& Watts, R. L. (2008). The Information Role of Conservatism. The Accounting Review, 83(2), 447-478. http://doi.org/10.2308/accr.2008.83.2.447

Lo, E. W. (2005). Pengaruh Tingkat Kesulitan Keuangan Perusahaan terhadap Konservatisme Akuntansi. In Simposium Nasional Akuntansi 8. Solo.

Lobo, G. J., \& Zhou, J. (2006). Did Conservatism in Financial Reporting Increase after the Sarbanes-Oxley Act? Initial Evidence. Accounting Horizons, 20(1), 57-73. http://doi.org/10.2308/acch.2006.20.1.57

Manganaris, P., Floropoulos, J., \& Smaragdi, I. (2011). Conservatism and Value Relevance: Evidence from the European Financial Sector. American Journal of Economics and Business Administration, 3(2), 254-264.

Ong, T. S., \& Ng, P. S. (2018). The Effects of Share Repurchase Announcements on Returns in the Malaysia Stock Market. Indonesian Journal of Business Finance and Accounting, 1(1), 1-19.

Rahmawati, R. (2006). Pengaruh Asimetri Informasi pada Hubungan antara Regulasi Perbankan dan Manajemen Laba serta Dampaknya terhadap Kinerja Saham: Studi Empiris pada Industri Perbankan di Indonesia. Universitas Gadjah Mada.

Safitri, T. A. (2012). Asimetri Informasi dan Underpricing: Studi Empiris di Bursa Efek Indonesia. Universitas Gadjah Mada.

Scott, W. R. (2012). Financial Accounting Theory (6th ed.). Pearson, Inc.

Shi-yu, X., \& Chang, L. (2008). A Theoretical Analysis of IPO Underpricing. China-US A Business Review, 7(4), 1-4.

Smith, C. W., \& Watts, R. L. (1992). The Investment Opportunity Set and Corporate Financing, Dividend, and Compensation Policies. Journal of Financial Economics, 32(3), 263-292. http://doi.org/10.1016/0304405X(92)90029-W

Srivastava, A., Sunder, S., \& Tse, S. (2015). Timely Loss Recognition and Termination of Unprofitable Projects. China Journal of Accounting Research, 8(3), 147-167. http://doi.org/10.1016/j.cjar.2015.05.001

Stiglitz, J. E. (2002). Information and the Change in the Paradigm in Economics. American Economic Review, 92(3), 460- 
501. http://doi.org/10.1257/00028280260136363

Sun, J., \& Liu, G. (2011). The Effect of Analyst Coverage on Accounting Conservatism. Managerial Finance, $37(1)$, 520. http://doi.org/10.1108/03074351111092111

Watts, R. L. (2003). Conservatism in Accounting Part I: Explanations and Implications. Accounting Horizons, 17(3), $207-$ 221. http://doi.org/10.2308/acch.2003.17.3.207

Widyaningsih, I. U., Gunardi, A., Rossi, M., \& Rahmawati, R. (2017). Expropriation by the controlling shareholders on firm value in the context of Indonesia: corporate governance as moderating variable. International Journal of Managerial and Financial Accounting, 9(4), 322-337. http://doi.org/10.1504/IJMFA.2017.10009973

Yu, F. (Frank). (2008). Analyst Coverage and Earnings Management. Journal of Financial Economics, 88(2), $245-271$. http://doi.org/10.1016/j.jfineco.2007.05.008

Yu, M. (2010). Analyst Forecast Properties, Analyst Following and Governance Disclosures: A Global Perspective. Journal of International Accounting, Auditing and Taxation, 19(1), 1-15. http://doi.org/10.1016/j.intaccaudtax.2009.12.001 